\title{
LISTY JANA ŁUKASIEWICZA DO KS. KONSTANTEGO MICHALSKIEGO
}

Ks. Michalski doceniał wartość listów, mając przekonanie, że stanowią one ważny dokument życia i działalności piszącego. Toteż wnikliwie analizował listy Władysława Natansona ${ }^{1}$, zbierał $\mathrm{i}$ omawiał listy Brata Alberta 2. Wystąpił także z inicjatywą ogłoszenia Epistolarium filozofów polskich ${ }^{3}$; w tej sprawie korespondował $\mathrm{m}$. in. z Kazimierzem Twardowskim ${ }^{4}$. Doceniając znaczenie listów skrupulatnie je przechowywał, zwłaszcza, gdy pochodziły od osób o wyjątkowo bogatym życiu duchowym.

W korespondencji ks. Michalskiego znajduje się 21 listów Jana Łukasiewicza ${ }^{5}$. Listy te, pisane z Warszawy, obejmują lata od 1928-1944. Adresatem jednego jest Polska Akademia Umiejętności; i ten jednak skierowany jest na ręce ks. Michalskiego. Trzy listy przechowały się $\mathrm{w}$ maszynopisie, pozostałe $\mathrm{w}$ całości są autografami, wypełnionymi starannym, łatwo czytelnym pismem. Jeden jest niekompletny, brak w nim drugiej strony, treść jednak łatwo zrekonstruować bez szkody dla zrozumienia zasadniczej tematyki. Dwa listy podpisane są przez Łukasiewicza $\mathrm{i}$ jego żonę Reginę $\mathrm{z}$ domu Barwińską ${ }^{6}$.

1 Por. Człowiek z Sympozjonu, Warszawa, 1937, ss. 12-14; Władystaw Natanson jako człowiek i humanista, „Acta Physica Polonica”, 6 (1937) 323.

2 Listy Brata Alberta do Lucjana Siemieńskiego, w: Księga Pamiątkowa na dziewięćdziesięciolecie dziennika „Czas" 1848-1938, Kraków-Warszawa, 1938, ss. 94-97; Brat Albert, Kraków, 1946, ss. 143-193.

3 Por. list ks. Michalskiego do St. Kremera z 8 października 1929 r. W AMS (Archiwum Księży Misjonarzy w Krakowie na Stradomiu).

4 Por. list K. Twardowskiego do ks. Michalskiego z 10 maja 1929 r. AMS.

5 Listy te mieszczą się w AMS. Do listów wymienionych nie zostało zaliczone pismo Ministerstwa W.R. i O.P. z dnia 27 czerwca 1919 r., podpisane przez Łukasiewicza jako ministra, w którym powiadamia, że Naczelnik Państwa postanowieniem z dnia 14 maja 1919 r. zamianowal ks. Michalskiego profesorem nadzwyczajnym filozofii chrześcijańskiej na U.J. AMS.

6 Eukasiewicz w przedmowie do pierwszego wydania Aristotle's syllogistic w tych słowach dedykuje cale dzieło swej żonie Reginie: „The whole work I 


\section{AUTOR LISTÓW}

Autor listów, jeden z najwybitniejszych logików XX w., współtwórca lwowsko-warszawskiej szkoły filozoficznej i warszawskiej szkoły logicznej, urodził się 21 grudnia 1878 r. we Lwowie. Studiował na uniwersytecie we Lwowie pod kierunkiem Kazimierza Twardowskiego, w Berlinie i Louvain. We Lwowie też uzyskał w r. 1902 stopień doktora filozofii, a w r. 1906 tytuł docenta. W latach od 1906-1915 wykładał jako docent we Lwowie. Od roku 1916-1939 był profesorem na uniwersytecie w Warszawie, gdzie też dwukrotnie, w latach 1922-1923 i 1931-1932, pełnił urząd rektora. Lata okupacji spędził w Warszawie. W r. 1944 opuścił Polskę i udał się do Münster w Westfalii, gdzie otoczył go opieką jego przyjaciel H. Scholz. Po zakończeniu wojny przebywał w Irlandii, gdzie od r. 1945 wykładał logikę matematyczną w Królewskiej Irlandzkiej Akademii Nauk w Dublinie. Zmarł 13 lutego 1956 r. w Dublinie 7.

Do głównych dzieł Łukasiewicza należą: $O$ zasadzie sprzeczności $u$ Arystotelesa (1910), Logika matematyczna (1929, 1958), Aristotle's syllogistic from the standpoint of modern logic $(1951,1957)$ oraz grupa rozpraw drukowanych w różnych czasopismach i wydanych później w zbiorze pt. $Z$ zagadnień logiki $i$ filozofii (1961). ${ }^{8}$ Wszystkie prace Łukasiewicza nacechowane są postawą antyirracjonalistyczną, niechęcią do wybujałej spekulacji filozoficznej oraz troską o poprawność i dokładność w myśleniu i wysławianiu się. Postawa taka nie zaprowadziła jednak Łukasiewicza na tory neopozytywizmu Koła Wiedeńskiego. W artykule $W$ obronie logiki pisał: „Nie odrzucam metafizyki, nie potępiam filozofii, do żadnego kierunku filozoficznego nie uprzedzam się z góry, nie uznaję tylko nieporządnej roboty myślowej" " ${ }^{9}$. Ceniąc rozum, który posługuje się ścisłą metodą naukową, nie lekceważył Łukasiewicz innych stron natury ludzkiej. W jednym z artykułów pisał: „Im więcej kto kształcić będzie zarówno rozum, jak i serce, im bliżej przestawać

dedicate to my beloved wife, Regina Eukasiewicz née Barwińska, who has sacrificed herself that I might live and work. Without her incessant care during the war, and without her continual encouragement and help in the loneliness of our exile after it, I could never have brought the book to an end", Oxford, 1958, s. IX.

7 Por. J. Słupecki, Stowo wstępne do pism wybranych Eukasiewicza pt. Z zagadnień logiki i filozofii, Warszawa, 1961, s. 8; „Studia Logica”, 5 (1957) 7. MEL (Mała Encyklopedia Logiki), Wrocław, 1970, ss. 162-163.

8 Bibliografię prac Eukasiewicza podają: „Studia Logica”, 5 (1957) 9-11. Uzupełnienie, „Studia Logica”, 8 (1958) 63; Z zagadnień logiki i filozofii, ss. 307-309. Twórczość Eukasiewicza omawiają m. in.: L. Borkowski - J. Słupecki, The logical works of J. Łukasiewicz, ,Studia Logica", 8 (1958) 7-56 i T. Kotarbiński, Jan Łukasiewicz's works on the history of logic, tamże, ss. 57-62.

9 Myśl katolicka wobec logiki wspólczesnej, Poznań, 1937, s. 9. Por. streszczenie tego artykułu $\mathrm{w}$ j. francuskim $\mathrm{w}$ : La pansée catholique et la logique moderne, Kraków, 1937, ss. 7-13. Swój stosunek do poglądów Koła Wiedeńskiego omówil Eukasiewicz w artykule pt. Logistyka a filozofia, „Przeglad Filozoficzny”, 39 (1936) $115-131$. 
będzie z wielkimi twórcami ludzkości, tym więcej tworczych pomysłów wysnuje ze swej bogatej duszy. I może kiedyś, w szczęśliwej chwili, zabłyśnie w nim iskra natchnienia, która pocznie rzecz wielką" ${ }^{10}$.

Łukasiewicz najwięcej miejsca poświęcił w swej twórczości logice, choć zajmował się również historią filozofii, psychologią i problemami metafizycznymi, zwłaszcza zagadnieniem przyczynowości i indeterminizmu. Zamiłowany był w refleksji logicznej, jak na to wskazuje następujące wyznanie: „Ilekroć zajmuję się najdrobniejszym nawet zagadnieniem logistycznym, szukając np. najkrótszego aksjomatu rachunku impijkacyjnego, tylekroć mam wrażenie, że znajduję się wobec jakiejś potężnej, niesłychanie zwartej i niezmiernie odpornej konstrukcji. Konstrukcja ta działa na mnie jak jakiś konkretny dotykalny przedmiot, zrobiony $\mathrm{z}$ najtwardszego materiału, stokroć mocniejszego od betonu i stali. Nic w niej zmienić nie mogę, nic sam dowolnie nie tworzę, lecz w wytężonej pracy odkrywam w niej tylko coraz to nowe szczegóły, zdobywając prawdy niewzruszone i wieczne. Gdzie jest i czym jest ta idealna konstrukcja? Filozof wierzący powiedziałby, że jest w Bogu i jest myślą Jego" 11.

Zdaniem Łukasiewicza historycy logiki, jak dotychczas, niewłaściwie przedstawiali logikę formalną. Historię logiki trzeba pisać na nowo, a pisać ją powinni tacy historycy, którzy gruntownie zapoznali się ze współczesną logiką. Sam Łukasiewicz zajął się przede wszystkim logiką Arystotelesa i stoicką. W swych badaniach wykazał, że logika stoików, $\mathrm{w}$ przeciwieństwie do logiki Arystotelesa, jest antyczną formą dzisiejszego rachunku zdań. Stwierdził również, że stoicka logika zdań dalej się rozwija w scholastyce, zwłaszcza w nauce o konsekwencjach. Według Łukasiewicza doskonałą formę aksjomatyczną logiki zdań podał w czasach nowożytnych genialny logik Gottlob Frege, w nowe zaś metody i tezy wzbogacił Peirce. Logikę taką rozpowszechnił B. Russell. Eukasiewicz doszedł do przekonania, że sylogizmy Arystotelesa są tezami logicznymi, podczas gdy sylogizmy stoickie - regułami logicznymi. Z tego punktu widzenia logika stoików różni się nie tylko od logiki Arystotelesa, ale także od współczesnej logiki zdań, która jest systemem tez logicznych ${ }^{12}$.

Rozważania Łukasiewicza nad poznaniem wytwórczym oraz nad przypadkowymi zdarzeniami przyszłymi naprowadziły go na pomysł logiki trójwartościowej (1920), nieskończenie wartościowej (1922) i czterowar-

10 O twórczości $w$ nauce, w: $Z$ zagadnień logiki i filozofii, s. 75.

$11 W$ obronie logistyki, s. 26.

12 Z historii logiki zdañ, "Przegląd Filozoficzny”, 37 (1934) 418-422; O determinizmie, w: $Z$ zagadnień logiki $i$ filozofii, s. 118; Uwagi filozoficzne o wielowartościowych systemach rachunku zdań. Przełożył Egon Vielrose, w: Z zagadnień logiki i filozofii, s. 163 . 
tościowej logiki modalnej (1953). Logika trójwartościowa zdaniem Łukasiewicza pojawia się już u Arystotelesa, w szkole epikurejskiej i u niektórych innych jeszcze logików starożytnych, podczas gdy stoicy, zgodnie ze swym poglądem deterministycznym, opowiedzieli się za logiką dwuwartościową. Powstanie logiki wielowartościowej porównywał Eukasiewicz do powstanie geometrii nieeuklidesowej z tym, że logika wielowartościowa ma jeszcze większą rolę do spełnienia w nauce i filozofii, aniżeli geometria nieeuklidesowa $\mathrm{w}$ matematyce ${ }^{13}$.

Łukasiewicz, budując swe systemy logiczne, dążył do jak największej prostoty. Dlatego szukał możliwie najkrótszych układów aksjomatycznych. Najważniejszym osiągnięciem jego w tej dziedzinie jest rachunek zdań oparty na jednym aksjomacie (Aksjomat Nicoda-Łukasiewicza) ${ }^{14}$.

H. Greniewski wyraził pogląd, że Eukasiewicz jest wprawdzie twórcą pierwszego trójwartościowego rachunku zdań, twórcą natomiast pierwszej logiki trówartościowej jest T. Kotarbiński. Sam jednak Kotarbiński oświadczył, że słusznie nie mówiono dotąd o jego „uczestnictwie w budowaniu pierwszego nowoczesnego logiczno-matematycznego systemu dedukcyjnego logiki wielowartościowej, zwłaszcza zaś o takim uczestnictwie, które by kwestionowało jedyność Jana Łukasiewicza" 15.

Wielu autorów w pomysłach Łukasiewicza znalazło podnietę do własnych badań. Ks. Michalski pod wpływem Łukasiewicza zajął się logiką trójwartościową $\mathrm{w}$ filozofii XIV w.16, ks. Jan Salamucha logiką zdań u Ockhama ${ }^{17}$, o. J. Bocheński zdaniami modalnymi ${ }^{18}$, A. Krokiewicz logiką stoików ${ }^{19}$, St. Schayer 20 i A. Kunst 21 logiką indyjską.

13 Uwagi filozoficzne, Ss. 161-163; Elementy logiki matematycznej. Skrypt autoryzowany opracowal M. Pressburger, wyd. 2, Warszawa, 1958, ss. 68-70; Znaczenie analizy logicznej dla poznania, „Przegląd Filozoficzny, 37 (1934) 375-377. Stanowisko swe wobec logiki trójwartościowej Łukasiewicza podał ks. K. Kłósak w dwu artykułach: Teoria indeterminizmu ontologicznego a trójwartościowa logika zdań Prof. Jana モukasiewicza, „Ateneum Kapłańskie, 40 (1948), t. 49, ss. 209-230; Konieczność wyjścia poza logikę dwuwartościowa, „Ateneum Kapłańskie 41 (1949), t. 50, ss. 105-116. Por. Filozofia $w$ Polsce. Slownik pisarzy, Wrocław, 1971, ss. $236-241$.

14 Por. MEL, ss. 3, 163. Z zagadnień logiki i filozofii, ss. 164-177.

15 Por. listy T. Kotarbińskiego i H. Greniewskiego do Redakcji Przeglądu Kulturalnego, „Przegląd Kulturalny” z 18 lutego 1962r. Por. L. Borkowski, Logika formalna, Warszawa 1970, ss. 252-256.

16 Le problème de la volonté à Oxford et à Paris au XIVe siècle, „Studia Philosophica", 2 (1937) 296-341.

17 Logika zdań u Wilhelma Ockhama, „Przegląd Filozoficzny”, 38 (1935) 208-239.

$18 \mathrm{Z}$ historii logiki zdań modalnych, Lwów, 1938.

19 O logice stoików, „Kwartalnik Filozoficzny”, 17 (1948) 173-197. Rozprawa ta jest częściową rekonstrukcją książki pt. Logika stoików (ok. 250 stron), zniszczonej w r. 1944.

20 Studien zur indischen Logik II: Altindische Antizipationen der Aussagenlogik, w: Bulletin inter. de l'Académie Pol. des Sciences et des Lettres. Classe de philol.; Classe d'histoire et de philos. année 1933 (wyd. 1934), ss. 90-96. Por. J. M. Bochenski, Formale Logik, Freiburg i. Br., 1956, ss. 485; 488.

21 Probleme der buddhistischen Logik in der Darstellung des Tattvasangraha, Krakau, 1939. 
Liczni uczniowie Łukasiewicza (J. Słupecki, M. Wajsberg, B. Sobociński i inni) podjęli idee twórcze Łukasiewicza i rozwijali je dalej.

\section{PRZEKEAD DZIEE ARYSTOTELESA}

Jednym $\mathrm{z}$ tematów, który się zjawia w listach Łukasiewicza, jest sprawa tłumaczenia dzieł Arystotelesa na język polski. W r. 1928 z inicjatywy ks. Michalskiego Wydział Historyczno-filozoficzny PAU przystąpił do realizacji przekładu pism Arystotelesa. W tym celu utworzono Komitet redakcyjny, którego przewodniczącym został Wł. Heinrich, pierwszym zaś sekretarzem ks. Michalski ${ }^{22}$. Na ręce ks. Michalskiego jako redaktora przesłał Łukasiewicz w dniu 5 maja 1928 r. swą odpowiedź na zaproszenie Akademii do współpracy nad przekładem dzieł Arystotelesa. W liście swym wyraża obawę, że mógłby podjąć się zadania, którego nie zdołałby wykonać, gdyż ma wiele prac już rozpoczętych a nie wykończonych. Do tłumaczenia pism Arystotelesa mógłby przystąpić dopiero za rok a może i później. Gotów jest jednak przełożyć niektóre traktaty, a mianowicie Hermeneutykę (De interpretatione) i Analityki (wcześniejsze). Istniejący już przekład Analityk wtórnych, dokonany przez Witolda Rubczyńskiego, należałoby przejrzeć. W każdym wypadku, gdyby sam nie był w stanie dokonać tłumaczenia, chciałby przynajmniej mieć udział w jego redakcji i gotów byłby dodać pewne objaśnienia. Ostatecznie Łukasiewicz zgodził się na redakcję przekładu czterech traktatów Organonu (Kategorie, O zdaniu, Analityki), podczas gdy opiekę nad tłumaczeniem Topik i Sofizmatów objął T. Kotarbiński. Ks. Michalski przejął na siebie trud tłumaczenia traktatu De anima ${ }^{23}$. Zamiary Łukasiewicza, podobnie zresztą jak i inicjatorów przekładu, nie zostały $w$ pełni zrealizowane, pobudziły jednak do tłumaczeń nie tylko pism Arystotelesa, ale także innych klasyków filozofii. Zamiary te tym samym stały się pewnego rodzaju źródłem powojennego cennego wydawnictwa, Biblioteki Klasyków Filozofii.

\section{ROZPRAWY LOGICZNE}

Już w liście z 5 maja 1928 r. wspomina Łukasiewicz o przygotowanej przez siebie monografii o sylogistyce Arystotelesa $z$ punktu widzenia współczesnej logiki matematycznej. Treść tej monografii, całkiem już wykończonej, przedstawił 9 czerwca 1939 r. na posiedzeniu PAU. Druk tego referatu (w streszczeniu), podobnie jak i rozpoczęty druk pełnej

22 Sprawozdanie $z$ wydawnictw $i$ czynności PAU od czerwca 1927 do czerwca 1928 , s. 22.

${ }_{23}$ Por. wykaz tłumaczy poszczególnych traktatów podany na okładce przekładu A. Krokiewicza Zarysów Pirrońskich, Kraków, 1931. Por. list T. Kotarbińskiego do ks. Michalskiego z 5 marca 1928 r. AMS. 
monografii, uległ zniszczeniu w czasie wojny. Spłonęła również w tym samym czasie biblioteka Łukasiewicza wraz z rękopisami prac przygotowywanych do publikacji ${ }^{24}$.

W liście z dnia 21 kwietnia 1943 r. Eukasiewicz notuje: „Nic nie mogłem zrobić przez zimę wobec stanu zdrowia. Zamierzam teraz, gdy przyjdzie lato, spisać przede wszystkim, choćby bez dowodów, wszystkie swe nieogłoszone wyniki rzeczowe i historyczne, zniszczone w notatkach przez pożar, aby ślad jaki po nich pozostał. Może się kiedy komu na co przydadzą". Niewątpliwie uwaga ta dotyczy również sylogistyki Arystotelesa. Faktycznie po wojnie, przebywając już za granicą, odtworzył Łukasiewicz wyniki swych badań, a owocem tej rekonstrukcji było dzieło Aristotle's syllogistic. Pierwsze wydanie tego dzieła nie zawierało jeszcze wykładu modalnej sylogistyki, gdyż Autor uważał, że nie jest $\mathrm{w}$ stanie na razie ocenić idei Arystotelesa dotyczących systemów modalnej logiki. By przezwyciężyć napotkaną trudność, postanowił zbudować własny system logiki modalnej. Pierwszy zarys takiego systemu, w związku z ideami Arystotelesa, podał w swych wykładach w Królewskiej Irlandzkiej Akademii Nauk w r. 1951 i w Królewskim Uniwersytecie w Belfaście w r. 1952. Pełny system tej logiki ogłosił w The Journal of Computing Systems (1953). System ten jest różny od jakiegokolwiek innego systemu logiki modalnej i dzięki temu, jak sądzi Łukasiewicz, można było wprowadzić pewne korekty do modalnej sylogistyki Arystotelesa 25. Nowy system dołączył Łukasiewicz do drugiego wydania swej Sylogistyki, choć sam nie doczekał się już publikacji tej edycji. Uczeń jego Czesław Lejewski przeglądnął korektę dodanych rozdziałów i uzupełnił skorowidz ${ }^{26}$.

W listach swych wspomina Eukasiewicz także o innych swych pracach logicznych. W liście z 22 września 1941 r. pisze: „Staram się coś robić i wymyśliłem system logiki, konsekwentny $\mathrm{w}$ sobie, w którym występują tylko zdania prawdziwe i fałszywe i w którym dwa zdania sprzeczne mogą być razem prawdziwe. System ten można zastosować do matematyki”. W liście zaś z 4 stycznia 1942 r. notuje: "Chcę się zabrać do intensywniejszej pracy naukowej na razie $w$ zakresie elementarnej arytmetyki. Potem będę próbował zastosować do niej pewien system logiki trójwartościowej, którym bez trudności można posługiwać się w matematyce". W liście z 20 grudnia 1936 r. pisze, że przygotowuje artykuł z dyskusji w Naukowym Instytucie Katolickim. Artykuł ten związany jest z III Polskim Zjazdem Filozoficznym, który się odbył

24 Aristotle's syllogistic from the standpoint of modern formal logic, Oxford, 1958, s. VII; Nota J. Słupeckiego w: $Z$ zagadnień logiki i filozofii, s. 220.

${ }_{25}$ Aristotele's syllogistic, s. V (przedmowa do drugiego wydania).

26 Aristotele's syllogistic, s. V (nota wydawcy). 
w dniach od 24-27 września 1936 r. w Krakowie. Z okazji tego zjazdu odbyło się 26 września spotkanie przedstawicieli filozofii chrześcijańskiej. Spotkaniu temu przewodniczył ks. Michalski, a udział w nim wzięli także zaproszeni goście, m. in. Władysław Tartakiewicz i Jan Eukasiewicz. Tematem dyskusji był stosunek myśli katolickiej do współczesnej logiki. W czasie spotkania Łukasiewicz wygłosił dwa przemówienia ${ }^{27}$.

W liście z 20 września 1937 r. powiadamia o swej rozprawie pt. Uwagi filozoficzne o wielowartościowych systemach rachunku zdań: „W pracy swej z r. 1930, z której niestety nie posiadam już odbitek, pt. Philosophische Bemerkungen zu mehrwertigen Systemen des Aussagenkalküls, wydanej w Sprawozdaniach Towarzystwa Naukowego Warszawskiego, Wydz. III., roczn. XXIII, 1930, wspominam o innych autorach starożytnych, którzy niewątpliwie pod wpływem Arystotelesa twierdzili, że zdania dotyczące przypadkowych zdarzeń przyszlych nie są ani prawdziwe, ani fałszywe. Byli to Epikurejczycy oraz Nikostratos. Może ta wiadomość zainteresuje Księdza Rektora".

Po otrzymaniu pracy ks. Michalskiego o problemie woli w Oksfordzie i Paryżu w XIV w., w liście z 31 października 1937 r., wyraża swą radość, że ks. Michalski zajął się zagadnieniem logiki trójwartościowej: „Jakże mi miło, że Ksiądz Rektor zainteresował się logiką trójwartościową i zajął się jej dziejami w średniowieczu. Jakie ciekawe wyniki okazały się przy tym, np. odkrycie poglądów trójwartościowych u Piotra Aureolusa i dojście do tego, kto to był ów tajemniczy „,doctor catholicus”. Dowiedziałem się z pracy ks. Rektora bardzo dużo nowych, a interesujących mnie rzeczy. Zagadnienia logiki trójwartościowej w wiekach średnich nie studiowałem nigdy. Teraz pod wpływem pracy Księdza Rektora wziąłem do ręki Prantla (nie rozporządzam innymi źródłami) i odkryłem w nim dzisiaj dodatkowe szczegóły, na które przedtem nie zwracałem uwagi". Autor listu cytuje następnie według Prantla szereg tekstów wyjętych z Ockhama i Roberta Holkota przemawiających za trójwartościowością zdań. Sądzi także, że dobrze byłoby przeglądnąć pod tym kątem traktat Ricarda de Capsali De futuris contingentibus, wydany razem z Expositio aurea Ockhama. Łukasiewicz uważa, że Boecjusz, relacjonując problem logiki trójwartościowej, mógł zaczerpnąć pewne wiadomości od Cycerona: pewniejszą jest jednak interpretacja, że korzystał z komentatorów greckich. Zdaniem Łukasiewicza stoicy jako determiniści gwałtownie zwalczali logikę trójwartościową Arystotelesa „ale może być, że właśnie przez kontrast u nich zarysowała się ta idea wyraźniej, niż u samego Arystotelesa”. Przy końcu listu dodaje: „Ja sam chciałbym kiedyś w jakimś artykule lub odczycie przedstawić 
całkiem popularnie genezę logiki trójwartościowej, bo to jest temat niezmiernie ciekawy".

W związku z własnymi pracami logicznymi interesował się także Łukasiewicz pracami innych logików. W liście z 20 grudnia 1936 r. wspomina, że O. J. Bocheński przesłał mu obszerny rękopis swej monografii $w$ j. francuskim o logice Teofrasta. Praca ta, jak wynika $z$ listu, miała się ukazać $\mathrm{w}$ pierwszym tomie czasopisma poświęconego logice i wydawanego $\mathrm{z}$ zapomogi Funduszu Kultury Narodowej. Monografia O. Bocheńskiego miała faktycznie ukazać się w Collectanea Logica pod redakcją Łukasiewicza. Została już nawet wydrukowana, ale cały nakład uległ zniszczeniu na początku wojny. Ukazała się dopiero w r. 1947 za granicą. ${ }^{28}$

\section{KANDYDATURY DO PAU}

W liście z dnia 13 października 1938 r. zajmuje Eukasiewicz stanowisko w sprawie proponowanych kandydatur do Polskiej Akademii Umiejętności. Cieszy się z kandydatury Adama Krokiewicza, z którym współpracuje już drugi rok, prowadząc razem z nim seminarium z filozofii greckiej. Gotów jest także oddać swój głos na Władysława Tatarkiewicza i Zygmunta Zawirskiego, pod warunkiem jednak, że przedtem lub równocześnie załatwi się sprawę dwu innych kandydatur: Stanisława Leśniewskiego i Tadeusza Kotarbińskiego. Stanisława Leśniewskiego uważa za pierwszorzędnego uczonego i dlatego, jak się wyraża, jego kandydaturę będzie zawsze najgoręcej popierał ${ }^{29}$. Wymieniając nazwisko Kotarbińskiego zaznacza, że prace jego ,z zakresu prakseologii, począwszy od zapomnianych już dzisiaj, a tak ładnych Szkiców praktycznych poprzez subtelne analizy z teorii czynu aż do najnowszej pracy $O$ walce, są cennymi pionierskimi badaniami w zupełnie nowej dziedzinie faktów". Łukasiewicz nie zgadza się z wieloma poglądami społecznymi, politycznymi i religijnymi Kotarbińskiego, ale nie może „tak jak wszyscy, którzy go znają, nie cenić jego szczerości przekonań i niezwykłej prawości". Łukasiewicz uważa także, że członkiem zagranicznym Wydziału winien zostać Henryk Scholz. Życzliwość, jaką Scholz okazuje w swych pracach dla Polski i dla polskich uczonych, jest stała i szczera. Dlatego ze strony Polski należy się mu jak największa wdzięczność ${ }^{30}$.

28 J. M. Bocheński, La logique de Théophraste, Fribourg en Suisse, 1947, s. 6.

29 O St. Leśniewskim por. krótkie wspomnienie Stefana Mazurkiewicza w „Przeglądzie Filozoficznym", 42 (1939) 115; D. Gromska, Philosophes polonais morts entre 1938 et 1945, „Studia Philosophica", 3 (1948) 46-51; E. C. Luschei, The logical systems of Leśniewski, Amsterdam, 1962; St. Slupecki, Leśniewski's protothetics, „Studia Logica, 1 (1953) 44-112; St. Słupecki, Leśniewski's calculus of names, „Studia Logica”, 3 (1953) 7-76; A. Grzegorczyk, The systems of Leśniewski in relation to contemporary logical research, „Studia Logica”, 3 (1955) 77-97.

${ }_{30} \mathrm{~W}$ wymienionym liście wspomina Łukasiewicz o artykule, w którym Scholz bardzo pozytywnie ocenił twórczość logiczną W Polsce. Artykuł ten ukazał się 
O kandydaturze Bohdana Nawroczyńskiego nie może na razie nic powiedzieć, bo pedagogika nie wchodzi w ramy jego zainteresowań i nie zna ostatnich prac kandydata. Zresztą inicjatorzy tej kandydatury nie prosili go o jej poparcie.

W liście z dnia 15 października 1938 r. Eukasiewicz z zadowoleniem przyjmuje do wiadomości, że kandydatura T. Kotarbińskiego jest przynajmniej w swej pierwszej fazie pozytywnie załatwiona. Równocześnie wyraża swój żal, że jak dotychczas nie zaaprobowano kandydatury Leśniewskiego. Cieszy się także, że poparto kandydaturę Scholza i dodaje: „Przyjaźń, jaką Scholz okazuje mnie i całemu naszemu środowisku, jest jednym $z$ najdziwniejszych i najmilszych przeżyć, jakie mnie w ostatnich latach spotkały. Jest to dla mnie jedno ze źródeł najczystszej radości".

Nieco wcześniej, bo już w r. 1937, z inicjatywy ks. Michalskiego postawiono kandydaturę samego Łukasiewicza. List z 29 marca tego roku jest świadectwem, że propozycja ta spotkała się z życzliwą aprobatą. Łukasiewicz nie wymienia wprawdzie wyraźnie samej sprawy, $\mathrm{z}$ tonu jednak podziękowania łatwo można wywnioskować, o co chodzi.

\section{KOEO NAUKOZNAWCZE}

Zarówno ks. Michalski jak i Łukasiewicz ściśle byli związani z zasłużoną dla rozwoju kultury polskiej Kasą im. Mianowskiego i ze Stanisławem Michalskim, dyrektorem Funduszu Kultury Narodowej ${ }^{\mathbf{3 1}}$. W liście z 23 stycznia 1938 r. przekazuje Eukasiewicz ks. Michalskiemu prośbę Stanisława Michalskiego o wygłoszenie odczytu w Kole Naukoznawczym istniejącym przy Kasie im. Mianowskiego na temat mniej więcej odpowiadający celom Koła. Uważa, że tematem odczytu może być np. metoda naukowa w średniowieczu lub stosunek filozofii średniowiecznej do nauki wieków średnich. Prośbę Stanisława Michalskiego popiera swą własną tym bardziej, że na posiedzeniu Koła Naukoznawczego on zwykle przewodniczy i zależy mu na tym, by wykłady w Kole były zarazem piękne i pouczające. List w krótkich słowach charakteryzuje klimat i działalność Koła: „Atmosfera w Kole jest bardzo miła, w tym właśnie gronie miał w przeddzień swej śmierci prześliczny wykład śp.

\footnotetext{
W „Philosophisches Jahrbuch d. Görres Gesel.”, 51 (1938) 257-291 pt. Die mathematische Logik und die Metaphysik. O H. Scholzu por. przedmowę T. Kotarbińskiego do polskiego wydania Zarysu historii logiki Scholza, Warszawa, 1965, ss. 5-7. ${ }_{31}$ W dniu 24 kwietnia 1932 r. wygłosił ks. Michalski przemówienie w związku z uroczystością pięćdziesięciolecia założenia Kasy im. Mianowskiego. Tekst przemówienia w AMS. Historię Kasy im. Mianowskiego podają: Z. Szweykowski, Zarys historii Kasy im. J. Mianowskiego, „Nauka Polska”, 15 (1935) 1-202; W. Osińska, Les débuts de recherches sytématiques sur la scientiologie dans le milieu varsovien au tournant des XIX et XX siècles, "Organon”, 6 (1969) 279-295.
} 
J. M. Rozwadowski. W najbliższą środę ja będę tam mówił o „Genezie logiki trójwartościowej". Odczyty odbywają się w pałacu Staszica, tuż obok kościoła św. Krzyża". Referat Rozwadowskiego, o którym wspomina Łukasiewicz, odbył się w dniu 13 marca 1935 r. na temat „Prawda życia”. W dyskusji nad wygłoszonym referatem zabrał głos także Łukasiewicz, wyrażając zadowolenie, że Rozwadowski zajmuje podobne stanowisko do filozoficznej szkoły warszawskiej. Stosowanie ścisłej metody naukowej nie prowadzi do skostnienia nauki, lecz do rozwiązania problemów i jest czymś żywym ${ }^{32}$.

Wzmiankowany w liście odczyt samego Łukasiewicza odbył się 26 stycznia 1938 r. Na posiedzeniu przewodniczył Czesław Białobrzeski. Autor wykładu stwierdził, że dotychczas nie myślano o tym, że mogą istnieć różne i niezgodne ze sobą systemy logiczne. Pojawienie się logiki wielowartościowej dowiodło, że mogą być różne systemy logiczne, konsekwentne w sobie i niesprzeczne, które różnią się między sobą i nie dadzą się do siebie sprowadzić. Każdy taki system logiczny może stać się podstawą dla innnej matematyki, a każda taka matematyka podstawą dla innej nieco fizyki. W dyskusji nad referatem zabrał głos także Stanisław Leśniewski. W przemówieniu swym odniósł się negatywnie do logiki trójwartościowej Łukasiewicza, podobnie jak do wszystkich innych logik wielowartościowych. ${ }^{33}$

\section{HABILITACJA KS. J. SALAMUCHY}

Na życzenie ks. Michalskiego zajął się Łukasiewicz sprax habrlitacji ks. Jana Salamuchy. Początkowo, jak wynika z listów ks. Salamuchy do ks. Michalskiego, ustosunkowany był do tego niechętnie ${ }^{34}$, z czasem jednak nabrał przekonania do osoby i działalności ks. Salamuchy. Co więcej stał się mu on $\mathrm{z}$ biegiem czasu coraz bliższym i duchowo pokrewnym. W liście np. z 24 grudnia 1941 r. tak pisze:" Z kochanym ks. Janem widujemy się co tygodnia, jest w całkiem dobrej formie i kontynuuje swe studia".

W liście z 25 marca 1933 r. Eukasiewicz wyraża gotowość napisania referatu z pracy habilitacyjnej ks. Salamuchy tym bardziej, że uważa go poniekąd za swego byłego ucznia. Zaznacza również, że miał i ma zamiar napisać recenzje o tej pracy do Przeglądu Filozoficznego. Z li-

32 Sprawozdanie o referacie Rozwadowskiego i o dyskusji nad referatem podaje „Nauka Polska”, 20 (1935) 250-256. O Rozwadowskim por. W. Strzałkowski, Jan Michat Rozwadowski, „Przegląd Filozoficzny”, 38 (1935) 142-144. Książka pt. Prawda życia, której odczyt był streszczeniem, została wydana przez A. Krokiewicza, Warszawa, 1937.

33 Por. „Nauka Polska”, 25 (1939) 215-223 (sprawozdanie o referacie i o dyskusji nad referatem).

34 Por. list ks. Salamuchy do ks. Michalskiego z 23 marca 1933 r. AMS. 
stu z dnia 7 października 1933 r. wynika, że na życzenie ks. Michalskiego zadzwonił w sprawie ks. Salamuchy do sekretariatu wiceministra W. R. i O. P., którym był wówczas ks. Bronisław Żongołłowicz. W tym samym liście dodaje: „Zgadzam się najzupełniej z Księdzem Rektorem, że ks. Salamucha wniesie coś nowego i że jest uzdolniony do pracy naukowej... Nakłaniałem go przy ostatniej bytności u mnie, by zajął się historią logiki średniowiecznej (Piotr Hiszpan, Duns Scotus, terminiści), która jest niezwykle ciekawa, a leży dotąd odłogiem, a którą może opracować tylko ktoś taki, co ma pojęcie o formalnej logice współczesnej".

W liście z 11 października 1933 r. referuje Łukasiewicz treść rozmowy, jaką przeprowadził $\mathrm{z}$ wiceministrem $\mathrm{w}$ następujących słowach: „Ks. Wiceminister nie powziął dotąd żadnej decyzji w sprawie ks. Salamuchy i pragnie pozostawić sobie jakiś czas do namysłu. Czytał sam początek pracy habilitacyjnej i nie zrobiła na nim dobrego wrażenia. Nie podoba mu się także, że ks. Salamucha habilituje się na podstawie pracy, za która dostał magisterium w Rzymie. Żałuje, że ks. Salamucha nie napisał nowej pracy dla celów habilitacji, pod kierunkiem jakiegoś profesora. Gdy w toku rozmowy zapytałem się dla własnej ciekawości, co stanie się z nową katedrą filozofii chrześcijańskiej w Krakowie, wywnioskowa $\in \mathrm{m}$ z odpowiedzi, że Ks. Wiceminister nie miałby nic przeciwko powierzeniu Ks. Salamusze wykładów zleconych (zastępstwo profesury możeby już nakładało pewne zobowiązania wobec kandydata). Ks. Salamucha, w razie, gdyby habilitacja jego nie została zatwierdzona, powinienby napisać nowa rozprawę lub choćby opracować gruntowniej obecną z uniknięciem błędów. Należałoby w każdym razie wydobyé z niego coś więcej, niż to, co dał dotąa". Nie trudno jest zinterpretować przytoczony tekst, gdy zna się inne dokumenty dotyczące osoby i prac ks. Salamuchy: w postawie i motywach wiceministra znać najwyraźniej wpływ osób, które kierowały się w tej sprawie racjami subiektywnymi.

Gdy trudności związane $\mathrm{z}$ habilitacją ks. Salamuchy zostały wreszcie pokonane, dzięki typowej dla ks. Michalskiego nieustępliwości i żelaznej woli w sprawach ważnych, Łukasiewicz w liście z 20 grudnia 1936 r. wyraził swą radość z pomyślnego wyniku starań.

\section{LATA WOJENNE}

Listy $\mathrm{z}$ czasów wojny charakteryzują ciężkie warunki pracy $\mathrm{w}$ tym okresie, a zarazem są dowodem pomocy, jakiej udzielał ks. Michalski Łukasiewiczowi przez ręce swych przyjaciół, zwłaszcza rodziny Popielów, przebywając po powrocie $z$ obozu koncentracyjnego na ziemi sandomierskiej. Szczegóły zawarte w tych listach odnoszą się do spraw pozornie bardzo dalekich od głębokiej teorii, mimo to należą do historii 
filozofii. Sw. Tomasz, do którego ks. Michalski stale zaglądał ${ }^{35}$, napisał w jednym ze swych dzieł, że są chwile, w których kawałek chleba wartościowszy jest od drogocennej perły ${ }^{36}$. Być może ta myśl przyświecała ks. Michalskiemu, gdy ze wsi sandomierskiej posyłał do Warszawy Eukasiewiczowi to, co wtedy było czymś bardzo cennym.

W liście z 21 września 1941 r. tak pisze Łukasiewicz: „Dwie kartki przybyły do nas z Sichowa, p. Popiel z Kurozwęk zjawił się osobiście, i paczka nadeszła od p. Brzechwy z makaronem i puszką konserw śledziowych. Za tyle troski, pamięci i serca najserdeczniej dziękujemy." W liście nieco późniejszym z 24 grudnia 1941 r. czytamy: „Mamy nadzieję przetrwać i tę zimę, choć cięższa jest od poprzednich... Ja sam mało teraz moge pracować, bo i światła często nie ma i zimno nieraz dokucza". W liście z 27 lutego 1942 r. dziękuje za przesłany cukier i mąkę obrazując równocześnie sytuację, w jakiej żyje i pracuje: „Przydało się to bardzo, bo tu wielka drożyzna, a zwłaszcza mąka, masło, słonina są bardzo drogie. Jesteśmy wzruszeni, że Ksiądz Rektor tak o nas pamięta. Czujemy się jako tako, tylko praca moja nie idzie zbyt sporo, bo nie mamy światła, w pokoju zimno, i siedzimy w kuchni przy małej lampce naftowej. Żona moja jest bardzo zmęczona, bo całymi dniami zajmuje się sama jedna gospodarstwem domowym, dwa razy w tygodniu przychodzi do pomocy kobieta".

W liście z 24 maja 1942 r. dziękuje za przesłany ser, dodając: „Część sera mogliśmy spożyć wspólnie z ks. Janem i p. Sobocińskim, którzy byli u nas zeszłego czwartku. Cieszymy się słońcem i zielenią. Żona moja trudzi się gospodarstwem domowym, sama sprząta i gotuje obiady, służącej stałej nie mamy, zabiega i troszczy się o wszystko, zwłaszcza o mnie. Ja pracuję nadal w Archiwum miejskim, a w domu pomagam żonie niewiele i staram się dokończyć niektóre drobniejsze prace".

Najcięższe chwile, jak się zdaje, przeżywał Łukasiewicz w r. 1943. W liście z 21 kwietnia tego roku pisze: „Wychudłem i czuję się słabo. Żona moja jest już także u kresu sił swoich, kaszle bezustannie i bardzo wychudła. Jest nam ciężko, odżywiamy się niedostatecznie, mięsa tygodniami nie mamy a tłuszczu zaledwie na okrasę. Nie tracimy jednak nadziei, że wytrwamy do końca. Otrzymałem pocztą $600 \mathrm{zl}$ od p. P. z Kurozwęk. Domyślam się kto był inicjatorem tej przesyłki i z głębi serca dziękuję". Nadzieja, jaką wyraził w powyższym liście, jest jeszcze

35 Por. Dokąd idziemy, Kraków, 1964, s. 16.

36 Quodlibetum primum q. 7 a. 13: Quaestiones disputatae et quaestiones duodecim quodlibetales, V, Taurini-Romae, 1931, s. 13: „Nihil enim prohibet, id quod est melius simpliciter, in aliquo casu esse minus eligendum; sicut philosophari est simpliciter melius quam ditari; sed in tempore necessitatis ditari est magis eligendum; et aliqua preciosa margarita est carior uno pane, et tamen in aliquo casu famis, panis praeeligeretur". 
bardziej zaakcentowana $\mathrm{w}$ ostatnim liście $\mathrm{z}$ dnia 6 kwietnia $1944 \mathrm{r}$. Do nadziei dołącza tu jeszcze pragnienie, zabarwione akcentem niemal pewności, że wkrótce będzie można poświęcić się pracy nad ulepszeniem form współżycia między ludźmi: „Oby to już były ostatnie święta wojenne, obyśmy mogli, skupiwszy się w spokoju, pomyśleć o pracy nad stworzeniem lepszych form współżycia ludzkiego. Pracy tej na swoim odcinku pragnąłbym poświęcić resztę życia swojego".

\section{S U M M A R I U M}

\section{DE LITTERIS JOANNIS EUKASIEWICZ AD CONSTANTINUM MICHALSKI SCRIPTIS}

In articulo primo de ipso Auctore litterarum, de eius operibus, eorumque scientifico valore agitur. Deinde principaliora themata litterarum breviter exponuntur, nempe: quaestio de traductione operum Aristotelis in linquam polonam, de dissertationibus logicis ipsius Łukasiewicz aliorumque auctorum, de candidatis ad Academiam Scientiarum Polonam, de actuositate Coetus Scientifici in Varsavia, de habilitatione Joannis Salamucha (postea professoris in Facultate Theologica Cracoviensi), denique de condicionibus vitae Joannis Łukasiewicz tempore secundi belli mundani. 